\title{
Effect of Dietary Minerals Supplementation on Growth and Carcass Yield in Broiler Chicken
}

\author{
Raina Doneria ${ }^{1}$, S.P. Tiwari ${ }^{1}$, Meenu Dubey ${ }^{1}$, M.K. Gendley ${ }^{2}$ and Rupal Pathak ${ }^{3 *}$ \\ ${ }^{1}$ Department of Animal Nutrition, College of Veterinary Science and A.H., Anjora, Durg- \\ 491001, Chhattisgarh Kamdhenu Vishwavidyalaya, India \\ ${ }^{2}$ Department of Animal Nutrition, ${ }^{3}$ Department of Livestock Production and Management, \\ College of Veterinary Science and A.H, Bilaspur-495 001, Chhattisgarh Kamdhenu \\ Vishwavidyalaya, India \\ *Corresponding author
}

\begin{tabular}{|c|c|}
\hline & A B S T R A C T \\
\hline & \multirow{6}{*}{$\begin{array}{l}\text { An experiment on } 120 \text { day old Ross } 308 \text { broiler chicken was conducted to study effect of } \\
\text { dietary supplementation of minerals ( } \mathrm{Se}+\mathrm{Zn}+\mathrm{Cr} \text { ) on growth performance and carcass } \\
\text { yield. Chicks were divided into three groups of } 40 \text { chicks in each and dietary treatments } \\
\text { consisted of minerals (Sodium selenite, Chromium picolinate, Zinc-methionine) in three } \\
\text { levels. Group } \mathrm{T}_{1} \text { was without additional supplementation minerals, group } \mathrm{T}_{2} \text { was } \\
\text { supplemented with minerals } \mathrm{Se}+\mathrm{Zn}+\mathrm{Cr} @ 0.15+25+0.30 \mathrm{ppm} \text { and group } \mathrm{T}_{3} \text { was } \\
\text { supplemented with minerals } \mathrm{Se}+\mathrm{Zn}+\mathrm{Cr} @ 0.20+50+0.50 \mathrm{ppm} \text {, respectively. In } \mathrm{T}_{3} \\
\text { group, cumulative feed intake was significantly }(\mathrm{p}<0.05) \text { low compared to } \mathrm{T}_{1} \text { during } 42 \\
\text { days of experiment. However, cumulative intake was significantly }(\mathrm{p}<0.05) \text { lower in } \mathrm{T}_{3} \\
\text { compared to } \mathrm{T}_{2} \text { upto } 28 \text { days, but later the value remained similar. Weight gain in } \mathrm{T}_{3} \text { was } \\
\text { significantly (p }<0.05 \text { ) higher on day } 28^{\text {th }} \text { and } 42^{\text {nd }} \text { as compared to other groups. The } \mathrm{T}_{3} \\
\text { group had best feed: gain ratio as compared to other groups }(\mathrm{p}<0.05) \text {. Weight of dressed } \\
\text { meat, wing piece, thigh and breast were significantly p }<0.05 \text { ) higher compared to other } \\
\text { groups. Thus, minerals supplementation improved growth performance, dressing } \\
\text { percentage and total carcass yield in } \mathrm{T}_{3} \text { group as compared to } \mathrm{T}_{1} \text { and } \mathrm{T}_{2} \text {. }\end{array}$} \\
\hline Keywords & \\
\hline $\begin{array}{l}\text { Dietary minerals, } \\
\text { Growth, Carcass } \\
\text { yield, Broiler } \\
\text { chicken. }\end{array}$ & \\
\hline Article Info & \\
\hline $\begin{array}{l}\text { Accepted: } \\
\text { 19 July } 2017 \\
\text { Available Online: } \\
\text { 10 September } 2017\end{array}$ & \\
\hline & \\
\hline
\end{tabular}

\section{Introduction}

Poultry industry is now witnessing series of problems such as various disease outbreaks, harsh climatic conditions and high cost of feed. The success of broiler production depends on maximum weight gain within minimum period, hence the poultry industry relies on the application of antibiotics to increase disease resistance. However, this practice has accompanied the prevalence and establishment of antibiotic-resistant species within the human populations (Phillips et al.,
2004). Thus appropriate alternatives for antibiotics maintain accessible markets for poultry products (Abdukalykova and RuizFeria, 2006). Minerals play a vital role in various metabolic, enzymatic and biochemical reactions ultimately leading to better growth rate, egg production and feed efficiency and are gaining importance as dietary growth promoters. Thus the current experiment was designed to study the effect of two levels of dietary supplementation of Selenium + Zinc + 
Chromium in combination on growth performance and carcass characteristics in broiler chicken.

\section{Materials and Methods}

Birds, Treatment and Management: The experiment was conducted in the Department of Animal Nutrition, College of Veterinary Science and Animal Husbandry, Anjora, Durg (Chhattisgarh) on 120 day old unsexed Ross 308 broiler chicks. Chicks were randomly allocated to 3 groups of 4 replicates in each group (10 chicks/replicate) in deep litter system under standard managemental conditions. The chicks were vaccinated against Marek's disease, New castle disease.

A typical diet based on feed ingredients like maize, soybean meal deoiled rice bran and fishmeal, dicalcium phosphate, and limestone powder were formulated for starter phase $(0$ 14 day), grower phase (15-28 days) and finisher phase (29-42 days) and presented in table 1 .

The starter, grower and finisher's diets contained 23, 21.5 and 20\% CP and 2900, 3000 and $3100 \mathrm{kcal} \mathrm{ME} / \mathrm{kg}$, respectively. Dietary treatments consisted of minerals (Sodium selenite, Chromium picolinate, Zincmethionine) in two levels. Group $\mathrm{T}_{1}$ was without additional supplementation of minerals. Group $\mathrm{T}_{2}$ was supplemented with minerals $\mathrm{Se}+\mathrm{Zn}+\mathrm{Cr} @ 0.15+25+0.30$ ppm Group $\mathrm{T}_{3}$ was supplemented with minerals $\mathrm{Se}+\mathrm{Zn}+\mathrm{Cr} @ 0.20+50+0.50$ ppm respectively.

Data Collection: Weekly live body weights were individually recorded for each chick and the average live body weights were calculated for each replicate and treatment during the five week of experimental period. Cumulative and weekly body weight gains were calculated for each chick, replicates and treatments. Feed consumption, feed conversion ratio were also recorded weekly for each replicate. Birds were slaughtered at the end of the experiment and carcass yield was recorded.

For interpretation of the result the data were subjected to Completely Randomized Design as suggested by Snedecor and Cochran (1994) and analyzed by ANOVA one way classification using SPSS package (SPSS ver. 10.0).

\section{Results and Discussion}

\section{Feed intake}

The feed intake during 0-14 days was significantly $(\mathrm{p}<0.05)$ lower in group $\mathrm{T}_{3}$ supplemented with mineral as compared to control $\mathrm{T}_{1}$ (Table 2). During 0-28 day the feed consumption was lowest in group $\mathrm{T}_{3}$ as compared to $\mathrm{T}_{2}$ and $\mathrm{T}_{1}$. On day 42 the cumulative feed consumption showed significant $(\mathrm{p}<0.05)$ reduction in group $\mathrm{T}_{3}$ as compared to its control group $\mathrm{T}_{1}$.

\section{Body weight gain}

In the present study, during 0-14 days no significant difference was observed in average weekly body weight gain in mineral supplemented group $\left(\mathrm{T}_{2}, \mathrm{~T}_{3}\right)$. On $28^{\text {th }}$ day a significant $(\mathrm{p}<0.05)$ increase in weight gain was observed in $\mathrm{T}_{3}$ as compared to control $\mathrm{T}_{1}$ (Table 2).

\section{Feed: gain ratio}

Birds in $\mathrm{T}_{3}$ group supplemented with mineral showed best feed: gain ratio as compared to $\mathrm{T}_{2}$ and $\mathrm{T}_{1}$ on $28^{\text {th }}$ day of the experiment $(\mathrm{p}<$ $0.05)$. Similarly, best feed: gain ratio was observed in the finisher phase also i.e. on $42^{\text {nd }}$ day (Table 2, $\mathrm{p}<0.05$ ).

The present findings are in agreement with other researchers (Toghyani et al., 2006; El- 
Hommosany, 2008; Tawfeek et al., 2014; Huang et al., 2016), who reported that supplementation of $\mathrm{Se}, \mathrm{Zn}$ and $\mathrm{Cr}$ increased body weight gain, feed: gain ratio and reduced feed intake in broiler chicken.

The probable reason for better feed: gain ratio in this study in supplemented group might be attributed to efficient nutrient digestibility. Oxidative damage of pancreatic tissue is protected by $\mathrm{Zn}$ and Se which may maintain secretory functions of digestive enzymes needed for efficient nutrient digestibility (Tawfeek et al., 2014). Supplemented dietary $\mathrm{Cr}$ in broilers enhances biological activity of insulin (Huang et al., 2016). Cr being an essential element for carbohydrate, fat and protein metabolism and modifies glucose metabolism through an oligopeptide known as chromodulin (Sun et al., 2000). Chromodulin consists of glycine, cysteine, aspartate, and glutamate, and binds with high affinity to 4 chromic ions. This enables $\mathrm{Cr}$ to be involved in the auto amplification of insulin signaling to maintain the active conformation of insulin receptors and cause greater glucose uptake (Vincent, 2000, 2001). The dietary supplementation of organic and inorganic selenium (Deniz et al., 2005; Sevcikova, 2006) improved the feed: gain ratio and the feather score of broilers. Due to the better feathering ability and the effect of Se on thyroid hormone activation there was reduction in the energy requirement of broilers for maintenance, which consequently improved the feed utilization efficiency.

Table.1 Ingredient and chemical composition of the experimental diet

\begin{tabular}{|c|c|c|c|c|c|c|c|c|c|}
\hline \multirow[t]{2}{*}{ Feed Ingredient } & \multicolumn{3}{|c|}{ Starter (0-14 d) } & \multicolumn{3}{|c|}{ Grower (14-28 d) } & \multicolumn{3}{|c|}{ Finisher (29-42 d) } \\
\hline & $\mathbf{T}_{1}$ & $\mathbf{T}_{2}$ & $\mathbf{T}_{3}$ & $\mathbf{T}_{1}$ & $\mathbf{T}_{2}$ & $\mathbf{T}_{3}$ & $\mathbf{T}_{1}$ & $\mathbf{T}_{2}$ & $\mathbf{T}_{3}$ \\
\hline Yellow maize & 53.0 & 53.0 & 53.0 & 56.40 & 56.40 & 56.40 & 59.7 & 59.7 & 59.7 \\
\hline $\begin{array}{l}\text { Deoiled soybean } \\
\text { meal }\end{array}$ & 36.40 & 36.40 & 36.40 & 33.40 & 33.40 & 33.40 & 26.3 & 26.3 & 26.3 \\
\hline Deoiled rice bran & 2.50 & 2.5 & 2.50 & 0 & 0 & 0 & 0 & 0 & 0 \\
\hline Fish meal & 2 & 2 & 2 & 2 & 2 & 2 & 5 & 5 & 5 \\
\hline Soyabeen oil & 2.40 & 2.40 & 2.40 & 4.60 & 4.60 & 4.60 & 5.5 & 5.5 & 5.5 \\
\hline $\begin{array}{l}\text { Di calcium } \\
\text { phosphate }\end{array}$ & 1.70 & 1.70 & 1.70 & 1.60 & 1.60 & 1.60 & 1.30 & 1.30 & 1.30 \\
\hline Limestone powder & 0.70 & 0.70 & 0.70 & 0.70 & 0.70 & 0.70 & 0.70 & 0.70 & 0.70 \\
\hline DL-methionine & 0.28 & 0.28 & 0.28 & 0.26 & 0.26 & 0.26 & 0.22 & 0.22 & 0.22 \\
\hline Lysine & 0.02 & 0.02 & 0.02 & 0 & 0 & 0 & 0.17 & 0.17 & 0.17 \\
\hline $\begin{array}{l}\text { Sodium } \\
\text { bicarbonate }\end{array}$ & 0.17 & 0.17 & 0.17 & 0.16 & 0.16 & 0.16 & 0.23 & 0.23 & 0.23 \\
\hline Common salt & 0.28 & 0.28 & 0.28 & 0.33 & 0.33 & 0.33 & 0.26 & 0.26 & 0.26 \\
\hline${ }^{1} \mathrm{Se}(\mathbf{p p m})$ & - & 0.15 & 0.20 & - & 0.15 & 0.20 & - & 0.15 & 0.20 \\
\hline${ }^{2} \mathrm{Zn}(\mathbf{p p m}$ & - & 25 & 50 & - & 25 & 50 & - & 25 & 50 \\
\hline${ }^{3} \mathbf{C r}(\mathrm{ppm})$ & - & 0.30 & 0.50 & - & 0.30 & 0.50 & - & 0.30 & 0.50 \\
\hline CP $(\%)$ & 22.95 & 22.95 & 22.95 & 21.46 & 21.46 & 21.46 & 19.76 & 19.76 & 19.76 \\
\hline ME kcal/kg & 2900 & 2900 & 2900 & 3000 & 3000 & 3000 & 3100 & 3100 & 3100 \\
\hline Ca $(\%)$ & 1 & 1 & 1 & 1 & 1 & 1 & 1 & 1 & 1 \\
\hline Available P (\%) & 0.5 & 0.5 & 0.5 & 0.5 & 0.5 & 0.5 & 0.5 & 0.5 & 0.5 \\
\hline
\end{tabular}


Table.2 Effect of dietary mineral supplementation on growth performance of broiler chicken

\begin{tabular}{lllll}
\hline Particulars & Period (Days) & \multicolumn{1}{c}{$\mathbf{T}_{\mathbf{1}}$} & \multicolumn{1}{c}{$\mathbf{T}_{\mathbf{2}}$} & \multicolumn{1}{c}{$\mathbf{T}_{\mathbf{3}}$} \\
\hline Feed intake (g) & 14 & $507.28^{\mathrm{b}} \pm 17.20$ & $507.56^{\mathrm{b}} \pm 9.04$ & $464.43^{\mathrm{a}} \pm 6.01$ \\
& 28 & $2070.72^{\mathrm{b}} \pm 9.5$ & $2032.16^{\mathrm{b}} \pm 55.17$ & $1841.96^{\mathrm{a}} \pm 21$ \\
& 42 & $4069.63^{\mathrm{b}^{\mathrm{b}} \pm 15}$ & $3738.96^{\mathrm{a}} \pm 83.60$ & $3704.8^{\mathrm{a}} \pm 53.80$ \\
Weight gain (g) & 14 & $410.70^{\mathrm{a}} \pm 6.48$ & $404.3^{\mathrm{a}} \pm 8.5$ & $422.35^{\mathrm{a}} \pm 8.85$ \\
& 28 & $1320.22^{\mathrm{a}} \pm 6.89$ & $1317.07^{\mathrm{a}} \pm 1.89$ & $1357.91^{\mathrm{b}} \pm 3.88$ \\
& 42 & $2273^{\mathrm{a}} \pm 2.87$ & $2242.92^{\mathrm{a}} \pm 10.6$ & $2401.38^{\mathrm{b}} \pm 21.5$ \\
Feed: gain & 14 & $1.23^{\mathrm{b}} \pm 0.04$ & $1.20^{\mathrm{b}} \pm 0.01$ & $1.09^{\mathrm{a}} \pm 0.02$ \\
ratio & 28 & $1.56^{\mathrm{b}^{\mathrm{b}} \pm 0.02}$ & $1.54^{\mathrm{b}} \pm 0.04$ & $1.35^{\mathrm{a}} \pm 0.02$ \\
& 42 & $1.79^{\mathrm{c}} \pm 0.02$ & $1.65^{\mathrm{b}} \pm 0.03$ & $1.54^{\mathrm{a}} \pm 0.03$ \\
\hline
\end{tabular}

T1: Se: 0, Zn: 0, Cr: 0 (ppm); T2: Se: 0.15, Zn: 25, Cr: 0.3 (ppm); T3: Se: 0.2, Zn: 50, Cr: 0.5 (ppm)

Table.3 Effect of dietary mineral supplementation on carcass characteristics of broiler chicken

\begin{tabular}{llll}
\hline Particulars & T1 & T2 & T3 \\
Live wt $(\mathrm{g})$ & $2216.66^{\mathrm{a}} \pm 42.4$ & $2316.66^{\mathrm{a}} \pm 123$ & $2567.66^{\mathrm{a}} \pm 123.6$ \\
Dressed meat $(\mathrm{g})$ & $1589^{\mathrm{a}} \pm 70.93$ & $1759^{\mathrm{a}} \pm 77.98$ & $1997.83^{\mathrm{b}} \pm 109.2$ \\
Liver $(\mathrm{g})$ & $78.36^{\mathrm{a}} \pm 3.72$ & $73.07^{\mathrm{a}} \pm 1.12$ & $71.86^{\mathrm{a}} \pm 4.15$ \\
Gizzard $(\mathrm{g})$ & $68.7^{\mathrm{a}} \pm 3.32$ & $64.74^{\mathrm{a}} \pm 4.37$ & $59.1^{\mathrm{a}} \pm 2.90$ \\
Heart $(\mathrm{g})$ & $10.63^{\mathrm{a}} \pm 0.23$ & $10.83^{\mathrm{a}} \pm 0.52$ & $9.86^{\mathrm{a}} \pm 0.31$ \\
Wing piece $(\mathrm{g})$ & $388.53^{\mathrm{a}} \pm 10.54$ & $457.66^{\mathrm{a}} \pm 39.95$ & $563.93^{\mathrm{b}} \pm 32.36$ \\
Thigh $(\mathrm{g})$ & $390.26^{\mathrm{a}} \pm 23.92$ & $448.86^{\mathrm{a}} \pm 10.39$ & $515.3^{\mathrm{b}} \pm 18.80$ \\
Breast $(\mathrm{g})$ & $184.27^{\mathrm{a}} \pm 9.73$ & $185.9^{\mathrm{a}} \pm 9.33$ & $231.6^{\mathrm{a}} \pm 14.10$ \\
Back and neck $(\mathrm{g})$ & $304.83^{\mathrm{a}} \pm 23.43$ & $341.86^{\mathrm{a}} \pm 11.88$ & $351.86^{\mathrm{a}} \pm 22.41$ \\
Giblet $(\mathrm{g})$ & $141.74^{\mathrm{a}} \pm 9.10$ & $149.56^{\mathrm{a}} \pm 8.36$ & $140.83^{\mathrm{a}} \pm 7.29$ \\
\hline
\end{tabular}

T1: Se: 0, Zn: 0, Cr: 0 (ppm); T2: Se: 0.15, Zn: 25, Cr: 0.3 (ppm); T3: Se: 0.2, Zn: 50, Cr: 0.5 (ppm)

\section{Carcass yield}

The weight of dressed meat, wing piece, thigh and breast was significantly $(\mathrm{p}<0.05)$ higher in $\mathrm{T}_{3}$ group as compared to other two groups $\left(\mathrm{T}_{1}\right.$ and $\left.\mathrm{T}_{2}\right)$. However, the different cuts of meat like liver, gizzard, back and neck and giblet did not show any significant $(\mathrm{p}<0.05)$ difference in their weight due to dietary supplementation of minerals.

The results are in agreement with the previous findings (Sahin et al., 2003; Onderci et al., 2004; Toghyani et al., 2006). These workers reported that $\mathrm{Cr}$ supplementation at varying levels increased carcass yield as well as weight of internal organs. It can be explained by the fact that $\mathrm{Cr}$ increases glucose and amino acid uptake into muscle cells and thus regulates muscle tissue formation leading to improve carcass quality. Rossi et al., (2007) reported improved carcass quality of broiler chicken due to supplementation of organic zinc $(0,15,30,45,60 \mathrm{ppm})$ in the diet. In the present study supplementation of $\mathrm{Zn}$ methionine in the diet at $50 \mathrm{ppm}$ improved carcass quality and dressed meat of broiler. The reason might be as $\mathrm{Zn}$ plays role in epithelial cell layers and collagen synthesis, thus affecting susceptibility of skin to tearing therefore improving carcass quality. Further, $\mathrm{Zn}$ enhances biological activity of body endocrine function particularly secretion of those hormones which play significant role in growth as well development of bones and growth (Yang et al., 2017). The dietary supplementation of organic and inorganic Se (Deniz et al., 2005; Sevcikova, 2006) improved the feed: gain ratio and the feather score of broilers (Table 3). 
Based on the present findings it was concluded that mineral supplementation in the ratio of $\mathrm{Se} 0.20+\mathrm{Zn} 50+\mathrm{Cr} 0.50 \mathrm{ppm}$ influences growth performances, carcass yield as evident by decreased feed intake, feed: gain ratio, while increased weekly body weight gain, dressed weight, wing, thigh and breast weight.

\section{References}

Abdukalykova, S., and Ruiz-Feria, C.A. 2006. Arginine and vitamin $\mathrm{E}$ improve the cellular and humoral immune response of broiler chickens. Intern. J. Poult. Sci., 5: 121-127.

Deniz, G., Gezen, S.S. and Turkmen, I.I. 2005. Effect of two supplemental dietary selenium source (mineral and organic) on broiler performance and drip loss. Revue. De. Med. Vet., 156(89): 423-426.

El-Hommosany, 2008. Study of physiological changes in blood chemistry, humoral immune response and performance of quail chicks fed supplemental chromium Intern. J. Poult. Sci., 7(1): 40-44.

Huang, Y., Yang, J., Xiao, F., Lloyd, K. and Lin, X. 2016. Effects of supplemental chromium source and concentration on growth performance, carcass traits, and meat quality of broilers under heat stress conditions. Biol Trace Elem Res., 170: 216-223.

Onderci, M., Sahin, K., Cizim, G., Vijaya, J. and Kucuk, O. 2004. Effect dietary combination of chromium and biotin on growth performance, carcass characteristics and oxidative stress marker in heat distressed Japanese quail. Biol. Trace. Element. Res., 106(2): 165-176.

Phillips, I., Case well, M., Cox, T., Groot, B., Friis, C., Jones, R., Nightingale, C., Preston, R. and Waddell, J. 2004. Does the use of antibiotics in food animals pose a risk to human health? A critical review of published data. J. Antimicro. Chemo, 53: 28-52.

Rossi, P., Rutz, F., Anciute, M.A., Rech, J.L. and Zauk, N.H.F. 2007. Influence of graded level of organic zinc on growth performance and carcass trait of broiler. J. Appl. Poult. Res., 16: 219-225.

Sahin, K., Sahin, N and Kucuk. 2003. Effect of chromium and ascorbic acid supplementation on growth carcass traits, serum metabolites and antioxidant status of broiler chicken reared at a high ambient temperature. Nutri. Res., 23(2): 225-238.

Sevcikova, S., Skrivan, M., Dlouha, G. and Koucky, M. 2006. Effect of selenium source on the performance and meat quality of broiler chicken. Czech. J. Ani. Sci. 51: 449-457.

Snedecor, G.W., and Cochran, W.B. 1994. Statistical Methods. $8^{\text {th }}$ Ed. Lowa State University Press, Ames, lowa.

Sun, Z.H., Tan, Z.L., Yao, J.H., Tang, Z.R., Shan, J.G., Hu, J.P., Tang, X.S. and Jiang, Y.M. 2007. Effects of intraduodenal infusion of limiting amino acids on plasma insulin-like growth factor I, growth hormone, insulin and liver insulin-like growth factor I mRNA in growing goat fed a maize stoverbased diet. Asian-Aust. J. Anim. Sci., 20: 733-741

Tawfeek, S.S., Hassanin, K.M.A. and Youssef, I.M.I. 2014. The effect of dietary supplementation of some antioxidants on performance, oxidative stress, and blood parameters in broilers under natural summer conditions. $J$. World's Poult. Res., 4(1): 10-19.

Toghyani, M., Shivzad, M., Gheisari, A.A. and Zarkesh, S.H. 2006. Performance, carcass trait and haematological parameter of heat stressed broiler chicks in response to dietary levels of 
chromium picolinate. Intern. J. Poult. Sci., 5(1): 65-69.

Vincent, J.B., 2000. The biochemistry of chromium. J. Nutri., 130: 715-718.

Vincent, J.B., 2001. The bio-inorganic chemistry of chromium (III). Polyhedron, 20: 1-26.
Yang, W., Chen, Y., Cheng, Y., Li, X., Wen, C. and Zhou, Y. 2017. Effects of dietary zinc bearing palygorskite supplementation on the carcass traits, chemical composition of muscle, and muscular lead and chromium contents of broilers. J. Poult. Sci., 54: 34-40.

\section{How to cite this article:}

Raina Doneria, S.P. Tiwari, Meenu Dubey, M.K. Gendley and Rupal Pathak. 2017. Effect of Dietary Minerals Supplementation on Growth and Carcass Yield in Broiler Chicken. Int.J.Curr.Microbiol.App.Sci. 6(9): 1414-1419. doi: https://doi.org/10.20546/ijcmas.2017.609.171 